Yıl: 23 Cilt: 23 Sayı: 2 Aralık 2021 s.200-219 Makale Türü: Araştırma

Makalenin Geliş Tarihi: 04.06.2021 Makalenin Kabul Tarihi: 10.12.2021

\title{
ABD Ulusal Güvenlik Strateji Belgelerinde Çin'in Yeri ve Hegemonik Düzen
}

\section{Elif Gürdal ${ }^{*}$}

Öz: Ulusal Güvenlik Strateji Belgeleri ABD’nin Soğuk Savaş sonrası yenidünya düzeni olarak tanımladığı ortamda kendine öngördüğü yol haritaları niteliğindedir. Reagan döneminde ilk kez yayımlanan ve belirli prensipler doğrultusunda bir sistematiğinin olması öngörülen bu Strateji Belgeleri hangi politik yaklaşım üzerinden güvenlik tedbiri alınacağını göstermektedir. Burada ABD’nin kendine tehdit olarak gördüğü unsurların çıkarımını yapmak mümkün olabilmektedir. Bu çalışmada; ABD’nin 1990’ların başında stratejik ortak olarak gördüğü ancak son on yılda stratejik rakip hatta kimi zaman düşman, kimi zaman ise istikrarsız bir risk unsuru olarak tanımladığı Çin, strateji belgelerinde kronolojik olarak ele alınmıştır. 1987'den itibaren on dokuz kez yayımlanan Ulusal Güvenlik Strateji raporları Çin’e uygulanması öngörülen politikaların dönüşümü ve nedenleri açısından incelenmiştir. Bu nedenler ise hegemonya anlayışı üzerinden araştırılmıştır. Dolayısıyla çalışma, yöntem olarak belgelerin kaynak olarak kullanıldığı, ilişkisel bir bağlantının ortaya çıkarılması hedeflenen nitel bir araştırmadır. Ana amaç Çin’in Soğuk Savaş sonrası yükselişinin strateji belgelerine güvenlik bağlamında hangi aşamalarda nasıl yansıdığını ve güç rekabetinde Strateji Belgelerinde ne yönde bir Amerikan tepkisine yol açtığını bulmaya yöneliktir. Burada hegemon konumdaki aktörün güç gerileyişi ile öncülüğünü ettiği hegemonik düzene katılım teşvikleri arasında bir bağlantının olduğu görülmektedir. Yeni hegemonik lider uzun vadeli güç rekabetinde bulunulan rakiplerden ziyade hegemonik düzene teşvik için önü açılan dost ülkelerden çıkabilmektedir.

Anahtar kelimeler: Ulusal Güvenlik Strateji Belgeleri, Hegemonya, Dünya Sistemleri Teorisi, ABD, Çin.

\footnotetext{
Dr. Öğretim Üyesi, Gümüşhane Üniversitesi, İktisadi ve İdari Bilimler Fakültesi, Uluslararası İlişkiler Ana Bilim Dalı, elif.gurdal@gumushane.edu.tr, ORCID: 0000-0001-5110-6524
} 
Year: 23 Volume: 23 Issue: 2 December 2021 p.200-219 Article Type: Research Received Date: 04.06.2021 Accepted Date: 10.12.2021

\title{
The Place of China in the US National Security Strategy Documents and the Hegemonic Order
}

\section{Elif Gürdal}

\begin{abstract}
National Security Strategy documents are the roadmaps that the USA envisages in the environment defined as the new world order after the Cold War. These strategy documents, which were published for the first time in the Reagan period show which political approach will be taken. These reports are based on the importance of the necessary security policies of that period. Here, it is possible to deduce the elements that the USA sees as a threat to itself. This work chronologically discusse China, which the USA saw as a strategic partner in the early 1990s, but defined as a strategic competitor, sometimes even an enemy, and sometimes an unstable risk factor in the last decade through strategy documents. As a method, the National Security Strategy reports published nineteen times since 1987 were examined through the transformation and reasons of the policies envisaged to be applied to China. These reasons were investigated through the understanding of hegemony. Therefore, the study is a qualitative research that aims to reveal a relational connection, in which documents are used as a source. The main purpose is to find out how China's post-Cold War rise was reflected in the strategy documents in the context of security and how it caused an American reaction in the Strategy Documents in power competition. Here, it is seen that there is a connection between the power regression of the hegemonic actor and the incentives for participation in the hegemonic order it leads. The new hegemonic leader may emerge from friendly countries, which are encouraged by hegemon actor for hegemonic order, rather than rivals with long-term power competition.
\end{abstract}

Key Words: National Security Strategy Documents, Hegemony, World Systems Theory, USA, China. 


\section{Giriş}

Amerikan Ulusal Güvenlik Stratejileri (UGS) 1986 yılında Reagan döneminde Goldwater-Nichols Savunma Bakanlığı Yeniden Yapılanma Yasası Kararı (Goldwater-Nichols Department of Defense Reorganization Act of 1986) ile başlayan ve ABD dış politika planını raporlayan belgelerdir (Goldwater-Nichols Act,1986: Title VI). 1987 yılından ilk UGS yayınlanmıştır. Şimdiye kadar 2021 yılı dâhil on dokuz UGS rapor yayınlanmıştır. Bu raporlar arasından uluslararası anlamda önemli olduğu düşünülen UGS'leri SSCB dağllmasından dolayı 1991 raporu, 11 Eylül saldırıları sonrası 2002 raporu, Trump yönetiminin 2017 raporu ve son yayınlanan ve Amerikan hegemonyasının yerini süper güç anlayışına bıraktığı belgelenen 2021 raporu olarak sıralanabilir. UGS raporları hegemon bir aktörün gücünü yeniden yapılandırmasından, gerilemesine kadar rakipleri ile hangi koşullarda rekabete gireceğine dair bir yol haritası niteliğinde olmaktadır.

Hegemonyaya güç üzerinden bakmak gerekmektedir. Gücü elinde olan aktör bunu arttırma eğiliminde olacak ve hegemon aktör olabilmek için rekabete girecektir (Modelski, 1987: 55-58). Hegemonik savaş sonrası hegemonyasını inşa eden aktör belirli sorumluluklarını yerine getirmek zorunda olacaktır. Burada uluslararası ilişkiler katılımcılarını bu hegemon konuma ikna etmek için de uygulanan rıza, yumuşak ve sert gücün dengesiyle uygulanarak sağlanabilmektedir. Akademik açıdan ise hegemonya kavramı farklı görüşler tarafından yorumlanmış ve bunlar; neorealist, neoliberal, Marksist açıdan uluslararası ilişkiler akademisyenlerince analiz edilmiştir. Bunlardan farklı olarak ise hegemonyayı döngüler üzerinden ele alan dünya sistemleri yaklaşımı yer almaktadır. Buna göre gücü azalan hegemon aktörün aşırı yayılmacılık gibi faktörlerle karşısına çıkan rakibine yenilerek yerini bu rakibine ya da üçüncü bir yeni hegemon aktöre bırakmasıyla belirli aralıklarla değişen hegemon döngüler uluslararası ilişkiler yapısını açıklamaktadır (Kennedy, 2001: 13; Modelski, 2005: 3-30; Wallerstein, 1997: 67). Hegemonya kavramını döngüler üzerinden açıklayan Immanuel Wallerstein, Andre Gunder Frank, Barry K. Gills, George Modelski ve Paul Kennedy gibi uluslararası ilişkiler uzmanları, kendi aralarında bakış açı farklılıkları olsa da döngüler üzerinden yapmış oldukları yorumlar itibari ile ortak noktada buluşmaktadırlar.

Günümüz hegemonya tartışmalarında ise ABD’nin artık hegemon aktör rolünü kaybettiği kanısı yaygın bir onay almış, uluslararası sistem istikrarı farklı aktörlerin düzen anlayışı çerçevesinde yeniden şekillendirme rekabetine girmiştir (Cooley and Nexon, 2020: 280-291). Keza dünya sistemleri yaklaşımının savunucusu Immanuel Wallerstein, 1980'lerden beri Amerikan gücünde gerileyişi ele alırken, diğer yandan neo-marksist Noam Chomsky, Giovanni Arrighi, David Harvey; realist Paul Kennedy ve liberal Richard Haass gibi akademisyenler de farklı nedenleri savunsalar da ABD'nin düşüşe geçtiği konusunda ortak noktada buluşmaktadırlar (Wallerstein, 2012:19-32; Chomsky, 2003; Arrighi 2000; Har- 
vey, 2007; Kennedy, 2001; Haass, 1999). Bu durumu özellikle pandemi sürecinin bir yansıması olarak küresel ekonomideki kötüye gidiş ve bu kötü gidişatın daha hassas bir sistem ile uluslararası işbirliğini olumsuz etkilemesi gibi nedenler açıklayabilmektedir. ABD'nin bu durumun olumsuz yanları ile başarılı mücadele edememesi hegemon konumunu artık kaybettiğinin göstergesidir (Cooley and Nexon, 2020: 280-291).

Mevcut uluslararası ilişkiler yapısı hegemonik bir rekabetten ziyade küresel liderlikte rekabet olarak nitelendirilebilir. Mevcut uluslararası ilişkiler yapısında $A B D$ ve Çin arasında yaşanan rekabet artık küresel liderliğin kimde olacağına dairdir. Zira hegemonya yaklaşımı daha kapsamlı ve belirli koşulların sağlandığı takdirde atfedilen bir rol olmaktadır. Yani küresel liderlik ile hegemonya arasında farklılıklar vardır. ABD’nin II. Dünya Savaşı sonrası yükselişi hegemonik yükseliş olarak tanımlanabilirken, özellikle 2001 sonrası sahip olduğu gücü sadece küresel liderlik olarak yorumlanabilir. ABD’nin günümüz güç tanımlaması ise Rusya, Çin, Hindistan ve diğer uluslararası güçler bağlamından bakıldığında süper güçler arası rekabet olarak nitelendirilmelidir. Bu açıdan hem ABD'nin hegemonik güç konumunda olmadığı hem de yeni bir ideal hegemon aktörün olmadığı düşünülürse, hegemonik bir rekabetten ziyade büyük güçlerin küresel mücadelesi söz konusudur.

Sahip olduğu hegemon konumu İngiltere'den devralan ABD, artık mevcut gücü bakımından hegemon konumunu kaybetmiş ve küresel bir güç olarak rakipleri ile uluslararası meselelerde öncülüğü paylaşma zorunda kalmıştır denilebilir (Cooley and Nexon, 2020: 280-291). Kendisine en önemli rakip ise Çin olarak görülmektedir (Haass, 1999: 37-49). Bahsi geçildiği gibi mevcut uluslararası ilişkiler ortamında henüz bu hegemonik bir rekabetten ziyade öncüler arası liderlik mücadelesidir. Çünkü hegemon olabilmek için yeni bir sistemin liderliği yapılarak diğer aktörlere sunulması gerekmekte, kurumsal olarak yapılanmalar kendini göstermekte ve ekonomik, askeri ve siyasi nüfuz bakımından diğer aktörlere oranla üstün bir konumda olmak gerekmektedir. Bu bakımda $\mathrm{ABD}$ hegemon konumunu kaybetse de ekonomik ve askeri üstünlüğünü korumaktadır. Ancak tüm bu koşulları sağlayacak bir rakip de söz konusu olmadığından mevcut uluslararası ilişkileri küresel güçler arası üstünlük mücadelesi olarak yorumlamak gerekecektir.

Bu mücadelede ABD son yıllarda Çin'i ciddi bir risk olarak görmektedir. ABD için bu risk faktörü konumunu SSCB'ye, Almanya'ya, Japonya'ya sonrası Rusya'ya ve ardından da Çin'e devretmiştir denilebilir. ABD-Çin ilişkileri seyrinde SSCB'nin dağılmasının ilk yıllarında özellikle Çin ile iyi ilişkilerin geliştirilmesi ve ticari ilişkilerde ayrıcalıklar ile ekonomisinin canlandırlması hedeflenirken, Çin'in 2000'lerden sonra hızla yükselişe geçmesi bir risk oluşturmaya başlamıştır. Artık, ABD, Çin'i ve Rusya'yı öncülüğünü ettiği serbest piyasa ekonomisinden istifade etmelerine rağmen liberal kurallara ve rejimlere uymakta sorunlar çıkaran agresif devletler olarak görmektedir.

ABD Çin’i 1990’ların başından itibaren açık pazara teşvik etmek için özel bir çaba harcarken artık Çin sert dille eleştirilerek stratejik bir rakip olarak görülmeye 
başlanmıştır. Bu değişen süreç ise bu çalışmada Amerikan UGS raporlarına yansıması bakımından irdelenmiştir. Çünkü çalışmanın amacı Çin’in Soğuk Savaş sonrası yükselişinin strateji belgelerine güvenlik bağlamında hangi aşamalardan, nasıl yansıdığını ve güç rekabetinde ne yönde bir Amerikan tepkisine yol açtığını bulmaya yöneliktir. Burada hegemon konumdaki aktörün güç gerileyişi ile öncülüğünü ettiği hegemonik düzene katılım teşvikleri arasında bir bağlantının olduğu görülmektedir.

Hegemonik düzene katılım için diğer aktörlerin teşvik edilmesinin eşit güçler arasında olmadığı görülmektedir. Çin'in, ABD ekonomik kapasitesine denk olabilecek seviyeye gelmesi ile serbest piyasaya katılımda teşvik edici unsurların sınırlandırılması bir ikilemdir. Süreç analizi, hegemonya yaklaşımlarında hegemon aktörün sınırlı teşviki koruması gerekliliğini göstermektedir. Bu duruma açıklık getirebilmek için de yayınlanan tüm strateji raporları tek tek analiz edilerek Çin konusunda ilk belge ile son belge arasında değişen yol haritası tespit edilmeye çalışılmıştır. Bu tespit hegemonya anlayışı üzerinden olmuştur.

\section{Dönemlere Göre Ulusal Güvenlik Strateji Raporlarında Çin}

ABD UGS raporları Soğuk Savaşın bitmesiyle birlikte düzenli olarak yayın yapılmaya devam etmiştir. İlk yayınlanan UGS 1987 yılında olmakla birlikte 1991'de resmi olarak sona eren Soğuk Savaşın ardından, yenidünya düzeni vurgusu ile UGS belgeleri, dönemin politik atmosferine göre farklı içeriklerle günümüze kadar bir yol haritası olarak dünya kamuoyuna duyurulmaya devam etmiştir.

Her bir Amerikan başkanı dış politikadaki güvenlik riskine, önemine, önceliklerine ve stratejisine göre farklı zaman aralıklarında ve sıklığında UGS belgelerini yayınlatmıştır. Yayın aralıkları dönemin başkanına bağlıdır (Goldwater-Nichols Act,1986: Title VI ). Bu bakımdan hem dönemsel dış güvenlik farklılıklarından dolayı hem de değişen dengeler itibari ile bu belgeleri 10'ar yıllık periyodlar üzerinden incelemek kronolojik açıdan daha verimli olacaktır. Ancak bu bölümün ilk başlığında Soğuk Savaşın bitimine yakın olan 1987 ve 1988 belgelerini ardından diğer başlıklarda sırasıyla 10'ar yıllık periyodları incelemek sağlıklı olacaktır. Böylelikle tüm belgeler hegemonik güç anlayışı üzerinden incelenmiş ve Çin'in Amerikan diş politikasındaki stratejik konumu verimli araştırılmış olacaktır. Kısacası ele alınan UGS belgeleri; ilk belgeler olan 1987 ve 1988 R. Reagan belgeleri, Soğuk Savaş sonrası ilk 10 yıllık dönem ile G. H. Bush ile W. Clinton yönetimi belgeleri, 2000 ile başlayan 10 yıllık periyod ile G. W. Bush belgeleri, 2010 ile günümüz 2020'ye kadar olan dönem B. Obama ve D. Trump yönetimleri belgeleri ve son olarak ise 2021 başkanlık seçilerini kazanan J. Biden'in başkanlığının ilk yılında yayınladığı 2021 ABD UGS belgesi olmaktadır. 


\section{7 ve 1988 UGS Raporları: R. Reagan}

Çin, Mao döneminden sonra 1976 sonrasında Komünist Partiyi ele geçiren ve iktidar olan reformist Deng Şaoping ile sosyal piyasa ekonomisini uygulamaya geçmiştir (Sullivan, 2016: xxxv). 1990’ların ortalarına kadar da ülke ekonomik olarak yükselişe geçmeye başlamıştır (Claus and Oxley, 2015: 1). Reagan döneminde ABD, SSCB'ye karşı zafere doğru ilerlerken, Çin bir tehdit olarak görülmemektedir. Hatta Çin'in SSCB'nin dağılımının da getirdiği yenidünya düzeninde serbest piyasa ekonomisine katılımı ile Amerikan hegemonik anlayışının güçlendirilmesi düşünülmektedir. Diğer yandan 1980’lerin sonralarında Çin dış dünya ile sorunsuz ilişkiler konusunda bir yol izlemiş ve ekonomik olarak yükseliş hedefinde ABD ile iyi ilişkilere önem vermiştir. Bu durum 1987 ve 1988 ABD UGS'ye yansımışırı. Keza ABD hegemonyası bakımından SSCB tehdidinin ortadan kalkmasına yakın daha güçlü çıkacağı bir ortamda Çin’i büyük bir tehdit olarak henüz görmemektedir.

1987 raporunda üç ana başarı ve beş ana Amerikan çıkarı ve beş strateji belirlenmiştir. Bu İlk UGS belgesinde ilk paragraflarda “ABD’nin liderlik rolü” cümleleri vurgulanmaktadır. Bu doğrultuda üç ana başarısından ilk başarısı SSCB'nin dağılmasına yakın olan politik atmosfer gereği SSCB konusunda gerçekçi politikalar uygulanması ve totalitarizm karşısında demokrasinin savunulması sık sık dile getirilmiştir. Dünya uluslarının demokrasiye ve serbest piyasa ekonomisine dönüşü ABD liderliğinde olduğu aktarılmıştır. İkinci başarısında ABD, SSCB tehdidi için ilk kez Batı Avrupa ve Doğu Asya'da askeri üs bulundurulduğunu, bunu da SSCB askeri yayılmasına karşı ABD askeri yayılmacılı̆̆ gösterilmiştir (National Security Strategy 1987:3). Belgede üçüncü başarı ise Avrupa’nın ve Japonya’nın “büyük $A B D$ ”nin yardımı ile refahını sağladığı aktarılmıştır (National Security Strategy 1987:3).

1987 UGS'de beş ana Amerikan hedefi ise ABD'nin kurumsal yapısının bozulmadan bağımsız olarak hayatta kalması, büyüyen bir Amerikan ekonomisi, uluslararası ticaret sisteminin demokratik kurumlar ile büyümesi, ABD çıkarlarına tehdit olmadan istikrarlı bir dünya ve son olarak ABD ittifak ilişkilerinin sağlığıdır. Bu ana hedefleri uygulamaya dökmek için ise beş strateji belirlemiştir. İlk olarak, ABD’nin düşmanca saldırıları caydırmak için girişimleri başarısız olursa devreye müttefikler girecektir. Avrasya'da SSCB ve benzeri bir aktörün hâkimiyeti engellenecektir. SSCB bölgede aşırı yayılmacılığını kaldırmayacak şekilde kendi içine kapanmaya zorlanacaktır. Bunun ise Çin ile daha yakın ilişkiler kurulacaktır (National Security Strategy 1987:15). Böylelikle Çin ile sınırlı ama basit olan iyi ilişkiler bu süreçte devreye girmektedir. ABD hegemonyası için yükselen ekonomisi ile henüz tehdit olmayan Çin'in bölgesel bir müttefik olduğu görülmektedir. Kaldı ki Asya'daki öncü müttefikin Japonya olması için öncelik yapılmıştır (National Security Strategy 1987:15). Çünkü bu yıllar dünyada en 
büyük ikinci ekonomik güç Japonya'dır. Hatta Japonya’ya ekonomik kapasitesine oranla savunma harcamasında eksik olduğu konusunda baskı yapılmaktadır (Gönen, 2004: 125). Yani hem siyasi müttefik olarak hem de askeri bir kale olarak Japonya'yı Asya'da öne çıkarmaya çalışmaktadırlar. Çin bu konuda bölgede sorun yaşamadığı ve iyi ilişkiler geliştirilen ülke konumunda kalmaktadır. Dolayısıyla UGS'de, Asya'da, Çin'den daha çok Japonya'ya ve ardından Güney Kore’ye yer verilmiştir (National Security Strategy 1987). Çin konusunda, büyüyen ekonomisi bir başarı olarak gösterilmekte ve ABD-Çin işbirliği her ne kadar Çin'in siyasi sistemi takdir edilmese de SSCB'ye karşılık olarak de teşvik edilmektedir. Böylelikle Çin stratejik hedeflerde Asya'da ancak üçüncü sırada önem verilen ülke olarak çok öne çıkmamaktadır.

1988 UGS'de SSCB ile yaşanan nükleer silahlanma yarışına yer verilmiştir. Belgede SSCB hegemonyası kesinlikle reddedilen bir dil kullanılmaktadır. UGS'de Çin'e yine çok öne çıkmayan bölgesel stratejilerin açıklanmasında ortak çıkarlar ve müttefiklik ilişkileri bakımından sınırlı bir öncelik verilmiştir (National Security Strategy 1988). Bu da sadece SSCB’ye karşı Çin’i serbest piyasa ekonomisine dâhil etmeye yönelik iyi ilişkilerin hedeflenmesinden kaynaklıdır.

1987-88 belgelerinde SSCB sonrası ABD hegemonyasının güçlenmesi, demokrasinin bir zafer aracı olduğu ve serbest piyasa ekonomisine geçiş Amerikan kültürü örnek alınarak yapılırsa fayda sağlanacağı üzerine ABD liderliği vurgusu yapılmıştır. Bu belgelerde öne çıkan ayrıcalık ise Batı Avrupa'da ve Doğu Asya'da SSCB'ye karşı ezici bir başarının müttefikler sayesinde kazanıldığı yönünde vurgu olması ve bunun devam edilmesi önerilen stratejilerin yer almasıdır. Doğu'da bu gücü daha da evrimleştirecek müttefik olarak ise Çin gösterilmektedir. Görüldüğü gibi Çin ABD’nin hegemonik olarak bir tehdidi değil, aksine başarısı takdir ve teşvik edilen Asya müttefiklerden biri olarak görülmektedir.

\section{0-2000 Arası Dönem: G. H. Bush ile W. Clinton}

Ocak 1989'da göreve gelen George H. W. Bush ile yeni döneme adapte olma çabaları görülmektedir. Bush diğer başkanlara oranla sahip olduğu tecrübeleri ile öne çımmaktadır. Bu yüzdendir ki diğer kutbun gücünü kaybetmesine rağmen belirsizlik dönemini iyi tanımlamaya çalışıp, tecrübelerini kullanarak tehdit algısını açmıştır. Büyükelçilik, CIA başkanlığı, Reagan dönemi başkan yardımcılığı görevleri başkanlığı süresince UGS'yi belirlemekte kullanacağı tecrübeler olacaktır.

1990 raporu SSCB'nin yaşamış olduğu dağılma sinyalleri üzerine oluşturulmuştur. Bu bakımdan Doğu Avrupa'daki ağır silahların ve nükleer silahların azaltılmasına yönelik ve SSCB üyesi devletlerin ekonomik reformlarının taslakları üzerine stratejiler ele alınmıştır. Burada Orta Asya veya diğer SSCB üyesi devletlerden ziyada Doğu Avrupa devletlerine yönelik stratejiler değerlendirilmiştir. "ABD hegemonik liderliği komünizm tehdidinden dünyayı korumada bir başarı kazanacaktı»” ifadeleri raporun öne çıkan yanlarıdır. Batı Avrupa ve Doğu Asya, 
ABD’nin hegemonyasına uyum sağlayarak başarıya ulaşan örnek ekonomiler olarak gösterilmiştir (National Security Strategy,1990: 6). İki kutuplu yapının sona ermesiyle Üçüncü dünya ülkelerinin çatışmacı yaklaşımlar sergileyerek bölgesel savaşlara neden olabileceği uyarısında bulunulmuştur (National Security Strategy,1990: 6). Bu uyarı ABD hegemonyasının çatışma giderici güç ve istikrar yöneticisi olarak görülmesi için olduğundan, ABD hegemonyasının gerekliliği vurgulanmıştır. 1990 UGS'de Çin yine öne çımmamakla birlikte dış dünya ile izolasyoncu yapısı yüzünden uyarıda bulunulmuş ve bu durumun ekonomik ve politik liberalizasyon bakımından zararlı olacağı aktarılmıştır. Çin ekonomik olarak izolasyondan açıklığa doğru daha da teşvik edilmiş̧ir (National Security Strategy,1990: 12)

1991 Raporu, Körfez Savaşının hemen ardından yayınlanmıştır. Bush, raporda çoğunlukla Soğuk Savaş sonrası ortamın nasıl değerlendireceği üzerinde dikkatli olunmasının gerekliliği üzerine durmuştur. Stratejide tek ve somut düşman algısının artık olmadığı vurgusu yapılmaktadır. Bu da Yeni Dünya Düzeni olarak adlandırıp çeşitli tehdit algılarının, farklı düşmanların olduğu aktarılmış, bunu yaparken de "Amerikan çıkarları her daim savunması en mühim unsurdur” yaklaşımı güdülmüştür. 1991 stratejisinde SSCB'nin dağılması sonrası SSCB coğrafyasının akıbeti, Avrupa'nın yeni yapısı, demokrasinin yayılması, nükleer silahlar konusunda ve de olası rakip olabilmeleri bakımından Almanya ve Japonya'nın büyüyen ekonomik rolleri üzerine durulmuştur (National Security Strategy, 1991:6). Bu gündem bakımından Çin öne çıkan bir stratejik değerde olmamaktadır. Ancak Çin'in ekonomik olarak izolasyona devam etmesi durumu karmaşık bir meydan okuma olarak algılanmıştır. Bu da ABD öncülüğündeki ekonomik sisteme entegre olması için Çin'in açık bir ekonomiye dâhil edilmesinin bir baskı olarak devam ettiğini göstermektedir.

1993 UGS raporunda ABD SSCB'nin dağılmasının ardından elde ettiği zaferi müttefiklerle paylaşacağını vurgulamıştır. Bu müttefiklere yönelik vurgu ABD hegemonyası için Irak’ta Körfez Savaşı esnasında önem kazanmıştır. Dolayısıyla 1993 raporu demokratik dünya düzeninin sağlanması için ABD hegemonyasının gerekliliği anlayışı ile demokrasi üzerinden ele alınmıştır. Önceki UGS raporlarında geçen Çin'in komünist parti ile olan siyasi yapısının farklılığına rağmen iyi ilişkiler sağlanacağı vurgusu değişmiş, artık ilk kez Çin'in demokratik bir reform yapmasının gerekliliği yeni raporda genel hedefler konusunda yer almıştır (National Security Strategy 1993: 1). Yani ABD hegemonik çıkarlarının gerekliliği için serbest piyasa ekonomisine entegre olmada karmaşık bir direniş göstermeye başlayan Çin'in iktidar yapısı bu defa eleştirilmiştir. Böylelikle Çin, ilk kez bir UGS'de ABD'nin bölgesel ülkeler değerlendirme başlığından çıkıp genel ulusal güvenlik meseleleri başlığına girmiştir.

1994 yılında Bush yönetimi ardından başkan olan Bill Clinton, UGS maddelerini günün koşullarına uygun bir şekilde belirlemiş, özellikle de ekonomik ve küreselleşme vurgusu ile ana temasını oluşturduğu stratejilerinden ilkini 1994'da 
yayınlamıştır. Başkan Clinton yönetimde kaldığı sürece her yıl strateji yayını yapmıştır. Bu bakımdan görevde kaldığı her yılda UGS raporu yayınlayan tek başkandır.

Bush yönetiminde iken hâkim olan Soğuk Savaş sonrası belirsizlik dönemi artık Clinton ile netlik kazanmaya başlamıştır. Clinton askeri açıdan ABD'nin her an savaşa hazır bir güçte olduğunu vurgulamıştır ve iktisadi canlanmanın ulusal güvenliğin bir parçası olduğunu belirtmiştir. Demokrasinin her yerde teşvik edilmesi gerekliliğine değinmiştir. Clinton da başkanlığının ilk yıllarında selefi Bush gibi müdahalelerde seçici davranılması gerektiğini vurgulanmıştır. Clinton, diplomasi ile dış politikanın uygulanması gerektiğini savunmuştur. Özellikle ABD ulusal çıkarları, ekonomik olarak serbest piyasanın gücü üzerinden müttefiklerin çoğalması ile daha da güvenli bir ortamda sağlanacaktır anlayışı yer almıştır.

1994 UGS raporunda yine nükleer silahsızlanma, bölgesel istikrasızlıklar ve eski Sovyet ülkelerindeki reform hareketlerine öncelik verilmiştir. 1994 raporunda Amerikan güvenliği için Füze Teknolojisi Kontrol Rejimi (MTRC) denilen nükleer silahsızlanma anlayışı taaddütleri konusunda Çin’e baskı yapılacağı yer almaktadır (National Security Strategy, 1994: 11). 1993’te MTRC taahhütlerine Arjantin katılmış, Rusya ve Ukrayna anlaşma imzalayarak katılacağını aktarmıştır (https://www.state.gov). Genel hatları ile 1994 raporunda nükleer silahsızlanma üzerine ve ekonomik olarak ABD'den sonra gelen ekonomik güçler olan Almanya ve Japonya'nın G7 aracılığı ile koordinasyona yöneltileceği stratejiler yer almaktadır.

Çin 1990’ların başından ABD için iyi ilişkiler geliştirilmesi gereken ülkeler listesinde iken artık 1993 ve 1994 UGS'de de görüleceği üzerine sorunlu ülke sinyallerini vermeye başlamıştır. Sağlanan ticari ilişkilerin kalıcı hale getirilmesi bakımından ABD'nin Çin açılımı 1990'ların ortalarında tartışmalı olmaya başlamıştır. 1980'de Çin'e verilen “En Çok Tercih Edilen Ülke” statüsü ile Çin menşeili ürünlerde vergi muafiyeti, 1994'te Çin'in insan hakları konusunda ihlalleri yüzünden ilk kez tartışma yaratmıştır (Devroy, 1997: 2). Zaten Çin’in demokrasiye pek yönelmeyeceği sinyalleri yine 1994 UGS'de vurgulanmış, ticari ilişkiler üzerinden sınırlı bir Çin stratejisi belirlenmiştir. Ancak insan hakları uyarılarına rağmen ticaretin devam edeceği aktarılmıştır (National Security Strategy, 1994: 24). Diğer yandan ABD’nin 1980’lerde başlayan Çin ile iyi ticari ilişkilerinde ABD ticaret açığı vermeye başlamış, önceki yıla göre en büyük ilk ticaret açığını 1994'te vermiştir. Bu oran 1994'te 29 milyon dolar açık iken yakın tarihte örneğin 2019'da 345 milyon dolar olmuştur (Office of the US Trade Representantive, 2021).

1995 UGS raporuna Çin’in önemli bir ekonomik güç olma yolunda ilerlerken hala daha baskıcı bir rejimi sürdürmesi yine bir sorun olarak yansıtılmıştır (National Security Strategy, 1995: 1) Hatta bu sorun bu sefer UGS raporunun henüz giriş kısmında raporun öne çıkanları arasında vurgulanmıştır. Çin’in ekonomik olarak büyümesi askeri kapasitesinin nüfus bakımından büyük olmasından dolayı kom- 
şularına tehdit olabilecek seviyeye gelmesi endişe yaratmıştır. Bunun için hem demokrasi için hem de bölgesel güvenlik mekanizmalarına katılım için sık sık baskı hedeflenmiştir (National Security Strategy, 1995: 29). ABD’nin rejim bakımından Çin'e uyarılar vermesine rağmen ticarete devam etmesini sağlayan Çin, bunu ABD’nin nükleer silah politikasına kısmen uyum sağlayarak sürdürmüştür. Yani 1995 UGS raporu Çin'in MTRC için verdiği garantiler üzerine olmuş, buna karşılık olarak da ABD sık sık Çin'i demokrasiye davet etmiş̧ olmasına rağmen ekonomik ilişkileri sürdürmüştür.

1996 UGS raporunda Çin bölgede önemli bir müttefik olarak vurgulanmış, Asya Pasifikte ekonomik olarak refah bir Çin'in ABD için daha fazla büyüyen bir piyasa ekonomisi anlamına geldiği ele alınmıştır. Hatta Çin'in DTÖ'ye katılımı için sürecin hızlandırılması kararı alınmıştır. 1997 Stratejisinde de yine müttefiklik vurgusu yapılmakla beraber Çin ile olan ilişskilerin izole Çin'den açık Çin'e geçiş için daha yakın, daha da derinleştirileceği sinyalleri verilmiştir (National Security Strategy, 1997). 1998 UGS raporunda Çin’i açık pazara dâhil etmek için çabalar sürmeye devam etmiş, hatta önceki raporlara oranla artan bir oranda Çin ve ekonomik ilişkilerden bahsedilmiştir (National Security Strategy, 1998: 4345). Bu stratejileri uygulamaya dökmek ve süreci hızlandırmak için Clinton Çin’e ziyarete gitmiştir (The US Department of State, 1998). İlk kez bir ABD başkanının Çin'e ziyareti söz konusu olmuştur.

1999 UGS raporunda Çin ile yapılan ikili anlaşmalar öne çımıştır. Clinton yönetiminde yine Çin ile başta ekonomik olmak üzere yakın askeri ve siyasi ilişkiler zorlanmıştır. Bundandır ki iki ülke nükleer silahları birbirlerine kullanmama kararı almıştır (National Security Strategy, 1999: 36). 2000 yılında duyurulan UGS'de ise Çin'in DTÖ'ye girmesine yönelik teşvikler artmıştır (National Security Strategy, 2000). Çin'e bu Stratejide daha fazla yer ayrılmıştır.

Clinton stratejilerine çok sert olmayan bir politikadan yana kullanmaktadır. Ancak halefi George Bush aynı politikayı yürütmeyecektir. 11 Eylül gibi büyük bir şokun yaşanması ve Amerikan tarihine damgasını vuran saldırı olması, Bush'un sert güçten yana olan aktif politikasının kaynağı olmuştur. Bu doğrultuda Clinton sonrası Bush döneminin Çin'e yaklaşımı başta güvenlik bağlamında uyarılar üzerine olmuştur. Hatta artık terörün yeni büyük bir tehdit olarak kendini göstermesiyle devlet bazında da olası tehdit edici aktörlerin raporlaması yoluna gidilmiştir.

\section{0-2010 Arası Dönem: G. W. Bush}

Bush, yönetimi boyunca iki kez UGS raporu yayınlamıştır. Bunlar 11 Eylül sonrası 2002'de ve yeniden seçildikten iki yıl sonra 2006'dadır. Bunlardan 11 Eylül olayının ardından yayınlanan rapor elbette ki ABD’nin saldırı sonrası izleyeceği yol haritası bakımından önem taşımaktadır. Başkan Bush 11 Eylül saldııları şoku sonrası $A B D$ gücünün bu tür olaylarla yıkılamayacağını ve gücünün gösterilmesi 
gerektiğini duyurmuştur. Uygulanması gereken stratejilerin ABD’nin gücünü sergiler tarzda olması gerektiğini savunmuştur. 11 Eylül ülke içi bir travmaya neden olmuştur. Çünkü ABD ilk kez kendi evinde bir terör saldırısına maruz kalmış ve yolcu uçaklarının bir füze gibi kullanılmasına şahit olmuştur. Bush Doktrini bu doğrultuda tek taraflı ABD çıkarlarını askeri güç ile müdafaa edilmesi gerektiğini, demokrasi yayılımının ABD’nin önderliğinde sağlanması gerektiğini savunmaktadır. Afganistan ve Irak müdahaleleri Bush doktrininin bu açıdan en büyük örnekleridir.

11 Eylül saldırlları ABD’nin küreselleşme ile gelen “büyük değişim” sürecini de kuvvetlendirmiştir. Ulus güvenliğinin yeniden şekillendiği ve askeri iletişimin kuvvetlendirilmesi gerektiği bir değişim sürecidir. Aslında bu değişim süreci 1980'lerde başlamış, 1990'larda uygulama alanı bulmuş, 2000'lerde 11 Eylül saldırılarının etkisiyle hızlanmıştır. Örneğin, Anavatan Güvenliği (Homeland security) Amerikan toplumsal hayatı için yapılan önemli değişim stratejilerdendir.

Bush dönemi bu sert stratejilerin kaynağı Neo-Con'ların yönetimde olmasına bağlanmıştır (Boot, 2004: 21). Bu Atmosferde ABD 2002 UGS'de Çin'in eski bir yol izleyerek halen daha demokratik değerlere geçiş yapmamasının ikili ilişsilerdeki tek engel olduğu aktarılmıştır. Çin'in büyüyen askeri kapasitesi konusunda bölgede tehdit olarak algılanmasından dolayı Çin'in kendi güç kapasitesine zarar verdiği düşünülmektedir. 2002 UGS'de üç önemli olası güç belirlenmiştir: Rusya, Hindistan ve Çin (National Security Strategy, 2002:26-27). Çin böylelikle ilk kez büyük güç kategorisinde ABD stratejilerine girmiştir. Diğer yandan 2002 stratejisinde Çin'in tekrardan açıklık ve demokrasi konusunda baskıya tutulması gerekliliği ortaya çıkmıştır. Ayrıca Çin, ABD’nin 100 milyar dolar üzerindeki hacmi ile en büyük dördüncü ticaret ortağı haline gelmiştir (National Security Strategy, 2002: 28). Böylelikle Çin'in güç rekabetinde oldukları bir aktör olma süreci başlamıştır.

Dört yıl sonra 2006'da yayınlanan yeni UGS'de büyümeye başlayan ekonomisine paralel olarak Çin'in yükümlülüklerini yerine getirme isteğinde sorunlar yaşanmaya başlandığı vurgulanmıştır. Küresel kurumlara bir zamanlar karşı olan Çin'in artık bir DTÖ ve BMGK üyesi olması ABD başarısı olarak değerlendirilmiştir (National Security Strategy, 2006). Ancak uluslararası sistemi yürütmede sorunlar yaşanmaya başlanmıştır. ABD küresel bir oyuncu haline gelmeye başlayan Çin'i kendisinden bağımsız olmasının önüne geçmeye çalışmaktadır. Bu süreçte Çin'in hegemonik bir tehdit potansiyeli olup olmadığı netlik kazandırılmaya çalışılmaktadır denilebilir. Bu bakımdan Çin konusundaki Amerikan endişeleri şeffaf olmayan askeri genişleme ile başlamıştır. Ardından küresel örgütlere katılım fakat ABD işbirliğine sorunlu yaklaşım ve piyasalara açılmak yerine yönlendirmeye çalışmak gibi meseleler sıralanmaktadır (National Security Strategy, 2006: 41). Çin'in kötü addedilen diktatör rejimleri enerji zengini olmalarından dolayı desteklemeye başlaması da ABD'nin önemli tehditleri arasındadır. Bunlar da elbette ABD'ni hegemonik stratejilerine tehditler olarak sıralanabilir. 


\section{0-2021 Arası Dönem: B. Obama ve D. Trump}

Başkan Obama, Bush'un aksine stratejisini diplomasi ve ittifaklar üzerine kurmuştur. Askeri üstünlük vazgeçilmemekle beraber ılımlı politikalar için daha itinalı davranılmıştır. Obama iki dönem başkanlık yapmasına rağmen sadece iki kez UGS raporu yayınlamıştır. Stratejiler genel hatları ile ABD vatandaş güvenliğine, müttefiklerin güvenliğine, ekonomik canlanmaya, İslam ülkelerinin nefretini kazanmamak için ılımlı politikalara ve iç güvenliğe ağırlık vermiştir. Bu stratejilerde katılımcı politikalar benimsenmiştir.

Obama yönetimi döneminde karşılaşılan ekonomik kriz neticesinde iç politikaya daha çok önem vermek zorunda kalınmıştır (Babal,2008). Dış politikada etkin olabilmek için iç dinamiklerin sağlamlığına önem veren Obama bunun için anavatan güvenliği ve ulusal güvenlik yapılarının istikrarına önem vermiştir. Bu bakımdan Great Depression'dan bu yana etkili olmayan ve şimdi ortaya çıkan bu kriz ortamında Amerikan liderliğinin yenilenmesi için yine ekonomik temelli önceliklerden başlanması gerektiği savunulmuştur.

2010 UGS raporunda beklenenin aksine Çin konusunda fazla stratejiye yer verilmemiştir. Küresel meselelerde Çin'in katılımcı olması ABD’nin liderlik rolüne uygun olarak görülmüş ancak askeri modernizasyon konusunda Çin'in takip edilmesi tedbiri ele alınmıştır. Bu yaklaşım 2015 strateji belgesine de yansımış, Çin'in askeri modernizasyonu artık bir tehdit olarak görülmeye başlanmıştır. Hatta strateji olarak Hindistan ekonomik bir potansiyel olarak, Çin yükselişe geçmiş bir tehdit olarak, Rusya ise saldırgan olarak nitelendirilmiştir (National Security Strategy, 2015: 4). Yeni bir Çin tehdidi olarak ise Çin'in üretim sistemi için Amerikan ticari sırlarının siber saldırı sonucunda ele geçirilmesinin önlenmesi için özel bir siber güvenlik stratejisi hedeflenmiştir (National Security Strategy, 2015: 24). Bu da artık Çin’e karşı ticari bir savaşın başladığının göstergesidir.

Ocak 2017'de yönetimi devralan Donald Trump ilk görev yılında UGS yayını yapmıştır. 2018'de ise genel stratejiler yerine Ulusal Savunma Stratejisi başlıklı rapor yayınlamıştır. 2017 UGS raporu Çin'in artık sert bir dille ele alındığı ve hegemonik rekabette bir rakip olarak net bir şekilde tehdit olarak dillendirildiği en açık ilk rapordur. Rusya ve Çin'in Amerikan gücünü aşındırmaya çalıştığı raporda vurgulanmıştır (National Security Strategy, 2017:25,27). Neredeyse 2017 UGS Çin üzerine bir belge haline gelmiştir.

2017 UGS raporu Obama dönemi sürdürülmeye çalışılan yumuşak güç ile Amerikan gücünü sürdürme çabalarının işe yaramadığını gösteren bir belgedir. Trump yönetimi sert yanlı bir güvenlik stratejisi ile öncülüğünü sürdürmeye çalışacağını göstermiştir. ABD’nin hegemonik gücünü kaybettiğini farkına varması anlamına gelen bu strateji ile, süper güç konumu ile uluslararası düzeni şekillendirmeye devam etmek istemektedir. Bu da güçler mücadelesine odaklanan bir strateji dizisi olduğu anlamına gelmektedir. 
Asya Pasifik dışında Afrika'da da bir rakip olarak görülen Çin'e, sert güç üzerinden düşman devlet kategorisinden meydan okunmuştur (National Security Strategy, 2017:52). ABD hegemonyasının gerileyişinden ziyade hızlandığını gösteren bu belgenin, devletleri ya dost ya da düşman olarak ikiye ayırması kesin hatların ve realist yaklaşımın işareti olmaktadır.

2017 stratejisi Amerikan güvenliğini tehdit eden meseleler arasında ABD fikri mülkiyetlerinin çalındığı ve ABD’nin liderliğindeki pazar piyasasından faydalanarak yine ABD'ye medyan okunduğu gösterilmektedir (National Security Strategy, 2017:7). Amerikan hegemonyası artık yerini büyük güçler arası rekabete bırakmıştır. Bu belge de bu rekabetin açık rakibi olarak Çin'i göstermektedir. Dolayısıyla hegemonik bir rekabet olmamakla birlikte güçler arası meydan okuma olarak görülmelidir.

Amerikan hegemonyasının yumuşak güç anlayışı olan rızaya dayalı katılım anlayışı artık 2017 ile birlikte sert yanlı politikalar üzerinden güç mücadelesine dönmektedir. Bu stratejiler çerçevesinde güvenlik ilk sıraya yerleşen öncelik olmuş, hatta Trump’ın görevdeyken yayınladığı 2018 yılındaki ikinci strateji belgesi sadece "Ulusal Savunma Stratejisi” (National Defence Strategy) belgesi olarak savunmaya odaklanmıştır. 2018 Savunma Stratejisinde yine Çin’in bölgesel hegemonyasını Asya Pasifikten ABD’yi uzaklaştıracak şekilde sürdüreceği öne sürülmüştür.

Askeri modernizasyonuyla ciddi bir tehdit olarak görülen Çin, ABD’nin 2018 stratejisinde belirttiği gibi yağmacı bir ekonomik anlayış benimsemesiyle de Asya Pasifikte kendi çıkarlarına göre düzenlemeler yapmaya başlamıştır (National Defence Strategy, 2018: 2). Rusya ve Çin'in ABD’nin II. Dünya Savaşından beridir kurduğu ve öncülüğünü ettiği uluslararası düzenin faydalarından istifade ettikleri ancak kurallarına da uymayarak kendi çıkarlarına göre yönetmeye çalıştıkları vurgulanmaktadır. Buna BMGK üyeliklerinde veto haklarını ABD gücünü baltalayacak şekilde kullanmaları örnek olarak gösterilmektedir (National Defence Strategy, 2018:2). 2018 stratejisinde ABD hegemonyasının zayıfladığı ancak ABD'nin kurmuş olduğu uluslararası düzenin sayesinde halen dayanıklı olduğu belirtilmiştir.

Trump dönemi Çin ticareti tam bir savaşa dönmüştür. Çin’den belirli ithal ürünlerinde aksine vergi artışına gidilerek bir rekabet söz konusu olmuştur. Aynı şekilde misilleme yapan DTÖ üyesi Çin böylesine bir ambargonun uygunsuzluğunu dile getirerek 2018'de ABD'yi DTÖ'ye şikâyet etmiştir (WTO, 2018). Hatta ABD de fikri mülkiyet haklarının çalındığı için Çin'i DTÖ’ye şikâyet etmiştir (WTO, 2018). Trump dönemi iyice kızışan ABD-Çin ticaret savaşı 1990’larla birlikte öne çıkan Çin’e yönelik vergi indirimlerinin ve ayrıcalıkların yaklaşık 30 yıl sonrası tersine döndüğünü göstermektedir. 


\section{J. Biden Stratejisi}

Trump'ın tartışmalı bir seçim süreci ile görevi Joe Biden'a bırakmasının ardından Biden, Trump gibi göreve gelir gelmez 2021 Martında ABD Geçici UGS'yi yayınlamıştır. Buna göre Trump Doktrini olarak açıklanan sert yanlı rekabetçi yaklaşım yerine diplomasi öncelikli müttefik ilişkilerine önem veren bir yaklaşımın geldiği aktarılmıştır. Genelde ABD başkanlığına gelindikten bir sonraki yıla hazırlanmış bir strateji yayınlanırken, Biden'in göreve geldiği ikinci ayda böylesine bir belge yayını yapması, Trump yönetiminden ayrılan çizgisinin vakit geçmeden yansıtılması gerekliliğinden kaynaklı olduğu söylenebilir.

2021 UGS'de Çin “iddialı ülke” olarak ele alınmıştır (2021: 8). Çin, Rusya ve diğer otoriter devletlerle bir rekabet vurgusu yapılmıştır. Rakipler olarak çoklu devletler belirlenmiştir. Ancak Çin, açık ve istikrarlı olması gereken uluslararası sistemi sekteye uğratacak ekonomik, diplomatik, askeri ve teknolojik gücünü birleştirebilen potansiyeldeki tek rakip olarak ayrıştırılmaktadır (Interim National Security Strategy, 2021: 8). Covid-19'un yaratmış olduğu küresel sorunların da ele alındığı bu belgede artan bir milliyetçilikten bahsedilmiştir (Interim National Security Strategy, 2021: 6). Diğer yandan gerileyen demokrasi de bir tehdit olarak görülmektedir.

2021 UGS raporunda uluslararası sistemin istikrarı için Amerikan gücünün yükselişi gerekliliği vurgulanmaktadır. Bunun ise tek başına yapılamayacak olduğu, müttefiklerden ve ittifaklardan yararlanılması gerekliliği belirtilmiştir. Burada açık bir şekilde Çin gibi ülkelere hesap sormak için ABD ve müttefikleri bir arada olmalıdır çağrısı vardır. Bu yeni strateji ile NATO üyeleri ve Avustralya, Japonya ve Güney Kore gibi ABD’nin Çin’e karşı stratejik üstünlük sağlayacak aktörlere yatırımlar yapılacağı belirtilmektedir (Interim National Security Strategy, 2021: 10). Bu da Çin’i kuşatma politikası için işbirliğinin teşvik edildiği anlamına gelmektedir. Diğer yandan savunma bütçesinin güçlü kalması için zorlanacağı belirtilmektedir. Bu da askeri güçte dünya lideri konumunu sürdürme gayretinin devam edeceği anlamına gelmektedir.

ABD'nin Çin'i geride bırakması için ve küresel liderlikte yeniden uluslararası gündemi Çin'in değil ABD’nin belirlemesi gerektiği aktarılmaktadır. Bunun için de küresel ittifaklara ve anlaşmalara ağırlık verilecektir. Görüldüğü üzere 2021 stratejisinde Çin'in rekabetine büyük bir ağırlık verilmiş ve ABD gücünün gerilemiş olduğu gerçekliği kabul edilerek bu boşluğun Çin tarafından doldurulmasına izin verilmemesi için müttefiklere çağrı yapılmıştır. Buradaki öncelik Çin'in komşularını ABD yanına çekmektir.

ABD yeni yol haritasında Çin'e karşı zafer kazanabilmek için Trump’ın düşman ilan ettiği ve ticari savaş ile sert yanlı bir politika benimsediği yaklaşımı telafi edilmeye çalışılacaktır. Trump'ın NATO’ya sert söylemleri, AB'ye buyurucu ifadeleri, uluslararası iklim sözleşmesi gibi bazı anlaşmalardan çekilme ka- 
rarı yerine Biden yönetimi ile birlikte artık bu kurumların modernizasyonu ile Çin'e karşı kullanma politikasına geçilmiştir. NATO ve AB'ye Çin'e karşı savaşta ABD’nin yanında olması için çağrı yapılmıştır. Tüm bunlar, ABD’nin uluslararası kamuoyunda yaşamış olduğu güven kaybını telefi edecek bir seçenek olarak görülmese de Çin ile ortaya çıkan güç mücadelesinde şimdilik ABD’nin liderliği sürdürdüğü görülmektedir.

\section{Sonuç}

Hegemonik güç anlayışı yapısal olarak değişmektedir. Uluslararası ilişkileri etkileyen aktörler devletlerle sınırlı kalmamaya başlamaktadır. Küresel anlamda devletlerin birbirlerine bağımlılığı Amerikan hegemonyasının ortaya çıkışı ile birlikte yaratılmaya çalışılan dünya düzenin bir sonucudur. ABD kurulan bu düzenin liderliğini, kontrolünü, kural koyunculuğunu ve yönetimini sağlayarak hegemon konuma erişmiş ancak bu rolünü gücün aşırı yayılması ve değişen uluslararası koşullar itibari ile kaybettiği tartışmaları öne çımaktadır. Küresel güç rolündeki ABD bu güce rakip çıkanlarla rekabete girişmiştir. Rusya ve Çin bu konuda tehdit olarak görülmekle birlikte askeri, siyasi, ekonomik ve teknolojik anlamda hepsini bir arada bulunduran potansiyel tek küresel rakibi Çin olarak görülmektedir.

ABD’nin Soğuk Savaş sonrasında hegemonyasını pekiştirecek unsurlar arasında ekonomik refahı olan devletlerin serbest piyasa ekonomisine açık katılımı gerekli olmuştur. Bunun için Çin ve sonrasında SSCB ardılı devletler reformlar ile teşvik edilmiştir. Çin ise siyasi yalnızlıktan korunmak için ABD ile ilişkilerine dikkat etmeyi seçmiştir. Böylelikle Çin'in yumuşama dönemine girmesi, Vietnam Savaşının ardından askerlerin bölgeden çekilmesi, Çin'e uygulanan ambargonun kaldırılması ve daha da sonrası Çin'in en çok tercih edilen ülke statüsü ile ekonomik olarak vergilerde pozitif ayrımcılığa erişmesi güç bakımından toparlanmasını sağlamıştır. ABD, Çin’in Komünist partili yönetim yapısını ekonomik katılımını teşvik etmek için göz ardı etmiştir. Tüm bu süreçler UGS raporlarına yansımıştır.

Amerikan 1987,1988, 1990 ve 1991 UGS raporlarında Çin bölgesel olarak yanına çekilmesi gerekilen bir devlet olarak görülmüş, izolasyondan ziyada açık bir dış ticaret benimsemesi için teşvik edilmiştir. Dolayısıyla bu raporlarda bölgesel politikalarda Asya Pasifik ile sınırlı değerlendirilen bir konumda kalmıştır. Asya Pasifikte bu yıllarda Japonya ve Güney Kore ile daha çok ilgilenilmiş, Çin önem sıralamasında gerilerde yer almıştır. Hatta Çin'e 1987 UGS'de sadece üç yerde o da bölgesel politikalar olmak kaydıyla değinilmiştir.

1993 UGS raporu ile birlikte Çin ilk kez bölgesel ilişkiler bakımından değerlendirilen ülke konumundan genel stratejiler alanına girmiştir. Bu da SSCB'nin dağılmasından dolayı piyasa ekonomisine geçişin teşvik edilmesi için ele alınmıştır. Ticari ilişkiler ile sınırlı bir ilişki stratejisi belirlenmiş, ancak 1994 UGS raporu ile Çin’in baskıcı yönetimi artık eleştirilmeye başlanmıştır. Zira izolasyonu 
hala korumaya çalışan yapısı artık ABD ile ticari ilişkilerinde ABD’nin ticari açık vermesine sebep olmaya başlamıştır.

1995, 1996, 1997, 19981999 ve 2000 yılları stratejilerinde ticari ilişkiler yürütülmeye devam etmiş, Çin’in askeri kapasitesi bölgede risk oluşturabileceği için ilk kez uyarılmaya başlanmıştır. Diğer yandan artık Çin'in DTÖ'ye üyeliği için konuşmalar da başlamıştır. Çin'e sık sık ABD’nin ticari açık vermemesi için izolasyondan daha da açık ticarete yönelmesi konusundan baskı yapılmıştır. Komünist rejim ticari ilişkiler için göz ardı edilmiş, buna karşı Çin ise nükleer anlaşmalara olumlu karşılık vermiştir. İlerleyen yıllarda Çin artık UGS raporlarında çokça yer verilen ülke konumuna yükselmiştir. Bu durum 1990’ların ilk yarısı tek rakamlarla sınırlı iken bu on yıllık dönemin son yıllarındaki raporlarda artık 30 ile 50 arası sayıda Çin'den bahsedilmeye başlanmıştır.

2000 ile 2010 yılları raporlarda Çin'in giderek potansiyel rakip olma yolunda yükselişi görülmektedir. 2002 raporunda Çin ilk kez ABD’nin potansiyel üç güç olarak tanımladığı Rusya ve Hindistan ile aynı gruba girmiştir. Çin artık ABD ile ticaret hacmi en yüksek olan dördüncü ülke kategorisine girmiştir. 2006 yılı itibari ile Çin'in büyümesi kontrol altından tutulmaya çalışılmıştır. Hem ticaret ilişkileri teşvik edilmiş hem de kontrollü büyüme hedeflenmiştir. Bu büyüme ile paralel olarak yükümlülüklerin yerine getirilmesi konusunda Çin uyarılmaya başlanmıştır. 2006 ile birlikte Çin askeri ve ekonomik açıdan dengeli uyarılar almaya başlamıştır.

2010 yılı yayınlanan stratejide Çin konusunda bir bakıma sessizlik oluşmuştur. Çin'in askeri modernizasyonunun giderek yükselen ekonomisiyle birlikte ABD için risk oluşturmaya başlaması bu sessizliğin sebebi olduğu söylenebilir. Bir sonraki 2015'te yayınlanan UGS raporunda artık Çin yükselişe geçmiş bir tehdit olarak nitelendirilmiştir. Hatta Amerikan ticari sırlarını riske sokan siber saldırıların kaynağı olması ile ticaret savaşının başlaması gerekliliği ortaya çıkmışır. 2017 ve 2018 UGS raporları Trump'ın etkisiyle de şimdiye kadar Çin konusunda belirlenmiş en sert rapor olmuştur. Çin'in Amerikan gücünü arındırmaya çalıştığı yağmacı bir ülke olarak nitelendirildiği bir dönem başlamıştır. Çin böylelikle düşman devlet kategorisine girmiştir. Bu savaşta DTÖ üyeliği üzerinden yürütülürken hegemonyasının kurulması aşamasında ABD'nin hegemonyası için oluşturduğu rejimlerin kendine bir silah olarak kullanıldığı görülmektedir.

Yayınlanan 2021 raporunda Çin yine rakip olarak görülmekle birlikte iddialı ülke olarak nitelendirilmiştir. Çin çoklu rakipler arasından ekonomik, askeri, siyasi ve teknolojik gücü bir arada kullanabilecek potansiyeli olan en etkili tek rakip konumuna yükselmiştir. ABD bu güç savaşında Çin’i komşuları üzerinden çevreleme politikası ile müttefik toplayarak egale etme stratejisi benimsemiştir. Çin, 1990’larda ABD hegemonyasının yeniden yükselişi için piyasaya katılıma zorlanan, hatta bunun için ABD tarafından vergilerde ayrıcalıklı davranılarak komünist rejimi ve insan hakları ihlalleri dahi göz ardı edilen bir süreçten, 30 yıl içerisinde, düşman addedilen, vergilerde iki kat artışa gidilen ve ambargo uygulanan potansiyel küresel güç için rakip konumuna geçmiştir. 
Tüm strateji belgelerindeki süreç göz önünde bulundurulduğunda Serbest piyasaya katılıma teşvik için diğer aktörlere liderlik yapan hegemon güç bu katılım konusunda belirli bir sınırı da kontrol etmek durumundadır. Bu süreç Çin üzerinden görülmektedir. Hegemon aktör güç gerileyişi sürecinde öncülüğünü ettiği hegemonik düzene katılım için teşviki belirli bir sınırda koruması gerekebilir. Yani hegemon aktör güç gerileyişinde bunu tersine çevirebilmek için öncülüğünü ettiği sisteme katılıma teşvik etmek istemektedir. Ancak bu durum nüfus bakımından büyük kapasiteli ülkelerin ekonomik katkısı ile olumlu bir sonuca sebep olabilecekken potansiyel rakibin de oluşması bakımından ve de askeri kapasitesi bakımından da bir risk unsuru olabilmektedir. ABD ve Çin arasındaki ikilem bu konuda ortaya çımaktadır.

Uluslararası ticaretin eşitler arası bir ticaretten ziyade zayıf ülkelerin olanaklarının hegemonik işleyişte öne çıkan ülkelere yönlendirilmesine dayandırıldığı düşünüldüğünde, Çin’in ekonomik olarak zayıf ve hegemonik gücü ekonomik açıdan destekleyecek ülke konumundan yükselişe geçtiği görülmüştür. $\mathrm{Bu}$ da eşitler arası rekabete evrildiği, dolayısıyla hegemonik güç içerisinde eşitler arası ticaretin, hegemonya anlayışında, sınırlı olması gerektiği söylenebilir. Yani, hegemonik düzenin sürdürülmesi için ekonomik katılım konusunda teşvik eşit güçler arasında değil, ekonomik güç bakımından zayıf ve güçlü ülkeler arasında olabilmektedir. Buradan yapılacak çıkarımla hegemonik güçlerin el değiştirmesi sürecinde yeni liderin uzun vadeli rakip halinde bulunulan aktörün değil de mevcut hegemonik işleyişe teşvik için imtiyazlar tanınan ve yükselişinin önü açılan aktörlerden çıkabileceği olasılığı görülebilir.

ABD hegemonyasının gerilemesiyle bu boşluğun Çin tarafından doldurulmaması için müttefiklere çağrıda bulunulmaktadır. ABD, hegemonik otoritesinin tartışmalı olduğu her süreçte hegemonyasının yeniden inşası için ittifak ve bölgesel müttefik ilişkilerine önem vermiştir. Yine 2021 ile yeniden müttefiklik ilişkileri üzerinden güç savaşı oluşacaktır. 2021 UGS belgesinde bölgesel müttefiklere ayrılan stratejiler genişlemiştir. Burada ise hegemonyanın yeniden inşası değil büyük güçler arasında liderlik savaşı söz konusu olmuştur. Yani, bu mücadele dünya sistemleri yaklaşımındaki hegemonik savaş sürecinden ziyade küresel güçler arası liderlik savaşıdır. Kaldı ki hegemonik değişim Çin’in ve uluslararası düzenin hâlihazırdaki yapısı ile henüz mümkün değildir. Çin henüz askeri ve teknolojik liderliği tek başına elinde barındıramamaktadır. Çin’in uluslararası düzen için bir rejim yapısının kural koyucusu olması henüz mümkün değildir. Çin'in fazla iç problemi vardır. ABD sık sık Çin'in iç sorunlarını son dönem UGS belgelerine yansıtarak bu durumu uluslararası kamuoyu gözünde meşrulaştırmaya çalışmaktadır. Diğer yandan Çin'in uluslararası ilişkilerin istikrarı için önerebileceği bir siyasi modeli yoktur. Bu konuda istekli olduğu da tartışmalıdır.

Dünya sistemlerindeki hegemonya döngülerinde bahsi geçen bu şartlar gereklidir ve aşırı yayılma ile gücünü kaybeden hegemon aktör kendisinden daha güçlü çıkmış bir rakibine yerini devretmelidir. Yeni bir sistem öncüsü ve kural koyucu 
askeri, siyasi, ekonomik ve artık teknolojik liderliği elinde barındırmalıdır. Çin dijital para piyasası ve teknoloji üzerinden böylesine bir öncü girişimi olmasına rağmen hegemon aktör koşullarının tümüne aynı anda henüz erişmemiştir.

\section{Kaynakça}

Arrighi, G. (2000), Uzun Yirminci Yüzyıl: Para Güç ve Çağımızın Kökenleri, Çev., R. Boztemur, Ankara: İmge

Babalı, T.(2008). ABD ekonomisi ve "Mortgage" krizi nereye gidiyor?, Uluslararası Ekonomik Sorunlar Dergisi(Dışişleri Bakanlığı Yayınları), sayı: XXVIII http://www.mfa. gov.tr/abd-ekonomisi-ve-_mortgage_-krizi-nereye-gidiyor_tr.mfa. (E.T. 01.06.2021).

Boot, M. (2004), Neocons, Foreign Policy, Slate Group, No. 140, (20-28).

Chomsky, N. (2003). Hegemony or Survival: America's Quest for Global Dominance. London: Henry Holt and Company.

Claus, I. ve Oxley, L. (Ed.). (2015). China's economy: A collection of surveys. Oxford: Wiley\& sons.

Cooley A and Nexon D (2020). Exit from Hegemony: The Unraveling of the American Global Order. Oxford: Oxford University Press.

Cooley, A., \& Nexon, D. H. (2020). (No) Exit from liberalism? New Perspectives, 28(3), 280-291. https://doi.org/10.1177/2336825X20934974

Devroy, A. (May 27,1994). Clinton gratnts China MFN, reversing campaign pledge, THE TECH Newspaper Cambridge, p.2

Goldwater-Nichols Department Of Defense Reorganization Act (1 Oct.1986). Public Law 99-433. 99th Congress, 100 STAT. 993

Gönen, H. (2004). ABD-Japonya güvenlik antlaşmaları: Oluşumu, evrimi ve sonuçları. Uluslararası İliş̧iler, 1(4), (115-139).

Haass, R. (1999). What to do with American Primacy? Foreign Affairs. No. 78: 5 37-50.

Harvey, D. (2007). Neoliberalism as Creative Destruction. The Annals of the American Academy of Political and Social Science, 610, 22-44. Retrieved July 29, 2021, from http://www.jstor.org/stable/25097888

Kennedy, Paul M. (2001). Büyük güçlerin yükseliş ve çöküşleri: 16. yüzyıldan günümüze ekonomik değişim ve askeri çatışmalar. (Çev. B. Karanakçı). İstanbul: Türkiye İş̧ Bankası Yayınları.

Linklater, A. ve Suganami, H. (2006). The English school of international relations: A contemporary, reassessment (First Edition). Cambridge: Cambridge University Press.

Modelski, G. (1987). Long cycles in world politics (First Edition). London: MacMillan Press.

Modelski, G. (2005). Küresel politikanın uzun döngüsü ve ulus-devlet, Uluslararası İlişkiler, 2(7),( 3-30).

Office of the US Trade Representative. (2021). https://ustr.gov/countries-regions/chinamongolia-taiwan/peoples-republic-china, (E.T. 01.06.2021).

R. Sullivan, L. (2016). Historical dictionary of the People's Republic of China (third edition). Boulder, NewYork, London: Rowman \& Littlefieldd.

The US Department of State (April 30, 1998). Speec of secretary of State Madeleine K. Albright in Beijing, China, https://1997-2001.state.gov/statements/1998/980430b. html. (E.T. 01.06.2021). 
The USA Departmnet of State (2021). Missile Technology Control Regime (MTCR), https://www.state.gov/remarks-and-releases-bureau-of-international-securityand-nonproliferation/missile-technology-control-regime-mtcr-frequently-askedquestions/, (E.T. 01.06.2021)

US the Department of Defense (2018). National Defence Strategy of the United States of America.

US the Department of Defense N. (1996). ational Security Strategy of the United States of America.

US the Department of Defense. (1987). National Security Strategy of the United States of America.

US the Department of Defense. (1988). National Security Strategy of the United States of America.

US the Department of Defense. (1990). National Security Strategy of the United States of America.

US the Department of Defense. (1991). National Security Strategy of the United States of America.

US the Department of Defense. (1993). National Security Strategy of the United States of America.

US the Department of Defense. (1994). National Security Strategy of the United States of America.

US the Department of Defense. (1995). National Security Strategy of the United States of America.

US the Department of Defense. (1998). National Security Strategy of the United States of America.

US the Department of Defense. (1999). National Security Strategy of the United States of America.

US the Department of Defense. (2000). National Security Strategy of the United States of America.

US the Department of Defense. (2002). National Security Strategy of the United States of America.

US the Department of Defense. (2006). National Security Strategy of the United States of America.

US the Department of Defense. (2010). National Security Strategy of the United States of America.

US the Department of Defense. (2015). National Security Strategy of the United States of America.

US the Department of Defense. (2017). National Security Strategy of the United States of America.

US the Department of Defense. (2021). Interim National Security Strategy of the United States of America.

US the Department of Defense1997 National Security Strategy of the United States of America.

Wallerstein, I. (1997). The capitalist world-economy. Cambridge: Cambridge University Press.

Wallerstein, I. (2012). Liberalizmden sonra (dördüncü baskı). Çev. Erol Öz.İstanbul: Metis Yayınları. 
E. Gürdal: ABD Ulusal Güvenlik Strateji Belgelerinde Çin'in Yeri ve Hegemonik Düzen

WTO(2021). China initiates WTO dispute complaint against additional US tariffs on Chinese imports, https://www.wto.org/english/news_e/news18_e/ds565rfc_27aug18_e.htm, (E.T. 01.06.2021).

WTO (2021). United States files WTO complaint on China's protection of intellectual property rights https://www.wto.org/english/news_e/news18_e/ds542rfc_26mar18_e. htm, (E.T. 01.06.2021) 